DOI:10.30842/ielcp230690152385

\author{
A. V. Shatskov \\ (Institute for Linguistic Studies, RAS, St. Petersburg)
}

\title{
HITT. NININK- AND LAT. NĪTOR
}

It is argued that the original meaning of Hittite ninink- is 'to move, approach'. The Hittite verb is related to Lith. ap-nikti 'to assault, beset', $i$-nikti 'to get down to, engage, attack', OCS po-niknoti 'to droop' and Greek vยі̃ко 'quarrel, strife, feud' and goes back to PIE *neik-, meaning 'to approach energetically' or similar. Since Lat. nìtor is semantically quite close to the Balto-Slavic verbs and is formally comparable, it is very likely that nitor also belongs to this root.

Keywords: etymology, Hittite, Lithuanian, Old Church Slavonic, Latin.

А. В. Шацков

(Институт лингвистических исследований РАН, Санкт-Петербург)

\section{Хет. ninink- и лат. nītor}

Данная статья посвящена уточнению значения хеттского глагола ninink- и его этимологическим связям. В имеющихся словарях и изданиях текстов ninink- часто интерпретируется как 'мобилизовывать', 'поднимать', 'двигать', причем предлагаемые переводы одних и тех же контекстов с ninink- нередко противоречат друг другу. Подробный обзор примеров сужает количество значений этого глагола и показывает, что исходным значением корня было, скорое всего, 'двигаться, приближаться'. Этимологически хетт. ninink- восходит к корню *neik-, к которому также относятся ст.-слав. (vbz)-niknoti, po-niknoti, лит. ap-nikti 'обступить, овладеть, напасть', $i$-nikti 'налечь на (работу), увлечься', др.-гр. vєі̃ко 'брань, ссора, вражда'. К этому же корню следует также возводить и лат. nītor 'опираться, напрягаться, стараться', которое семантически достаточно близко литовским и славянским глаголам и может быть формально сопоставлено с ними.

Ключевые слова: этимология, хеттский язык, латинский язык, литовский язык, старославянский язык.

Even though Hittite ninink- is very well attested throughout all periods of Hittite, its semantic interpretation is not always clear. CHD L-N: 438 gives the following translations: 'to mobilize, set (people) in motion; to move, remove, transfer (something or someone)' as well as 'to behave in a disorderly manner (middle)', 'to disturb, agitate', 'to break open' and 'to loosen, detach'. Puhvel's translations are 'to move, stir, start', 'to soak', 'to engage', 'to rally' (HED N: 110). According to Tischler (HEG N: 328), ninink- means 
'in Bewegung setzen, antreiben; bewegen; in Aufruhr versetzen, stören; lösen, erbrechen; sich aufrührerisch benehmen, sich erheben'. Alternatively, ninink- is interpreted as 'to raise' (Oettinger 2009, LIV: 451). Yet differently, Ünal (1996: 34f.) suggests that the basic meaning for this verb is 'to disturb'. Therefore it is not surprising that there is a significant difference in interpreting some passages with ninink-, e.g.:

$n=$ at namma $\bar{U} L$ kuiski ninikzi (KBo 11.14 IV 19) is translated as 'nobody accesses it [viz. sealed building] further' in HED N: 111 and 'No one shall break it open again' in CHD L-N: 442, sim. Ünal 1996: 32. The latter interpretation is clearly based on kinuzi in the duplicate KUB 43.57 IV 17.

$n=u$ s nininker (KUB 14.1 obv. 72) is traslated as 'and they (the enemy) threw them into confusion. (They killed Kišnapili and Partahulla)' in CHD L-N: 442 and '(they came, blocked the path of our troops,) and engaged them' in HED N: 114.

In the Middle and New Hittite texts ninink- refers to an initial stage of military campaigns. When ninink- is transitive, its object is usually troops, and in the following sentence the leader sets out for a campaign. In such contexts ninink- is often interpreted as 'to mobilize', e.g. KBo 16.14 II 14-15 + KBo 16.8 II 29-30 nu GIM-an hameshanza ki[sat] $[n] u$ ERÍN ${ }^{\mathrm{MESS}}$ ANŠE.KUR.RA ${ }^{\mathrm{MEŠ}}$ nininkun $n u$ INA ${ }^{\mathrm{URU}}$ Tum[anna] [p] $\bar{a} u n$ 'when spring came I mobilized infantry and chariotry' (HED : 113, sim. CHD L-N: 439). Since this passage is followed by $n u$ INA ${ }^{\mathrm{URU}}$ Tum[anna] [p]āun 'and I went to Tumanna', ninink- cannot mean 'to move' or 'to set in motion' here. Cf. also KBo 5.6 II 26-27 $n u=z a \quad A B U=Y A \quad$ ERÍN $^{\mathrm{MES̆}}$ ANŠE.KUR.RA ${ }^{\mathrm{MESS}}$ ninikta $n=$ as $\mathrm{L}\left[\mathrm{U}^{\mathrm{ME}}\right]^{\mathrm{S}}$ Hurri iyannis 'My father mobilized (his) infantry and chariotry and marched [toward] Hurri' (CHD L-N 439) or HKM 20 6-9 nu annin 1 LIM 7 ME 60 ÉRIN $^{\mathrm{MEŠ}}$ ${ }^{\mathrm{URU}}$ Ishupitta lilihuwanzi ninikten $n=a n$ MAHAR ${ }^{\mathrm{D}} \mathrm{UTU}-\breve{S} I$ INA UD. $2^{\mathrm{K}}\left[{ }^{\mathrm{AM}} \mathrm{URU} S\right.$ S $]$ apinuwa lilihuwanzi uwatten '(As soon as this tablet reaches you (pl.)), quickly mobilize (pl.) that 1760-man troop of Ishupitta and lead (pl.) it to My Majesty in Sapinuwa in two days' (Hoffner 2009: 132).

In the latter example it is clear that ninink- refers to an already existing unit, therefore at least in some passages ninink- does not imply raising new troops. Some further examples are KUB 19.37 III 8-9 $n u=m u$ KARA ${ }^{\text {Hl.A }}$ kue kattan $[\bar{e} s t a] \quad[n=a]$ t nininkun 'the armies which were with me I rallied' (HED N: 113) and HKM 79 11-14 [nu k] inuna mān EGIR-pa [ERÍN ${ }^{\mathrm{MESS}}$ k] uiēska uwanzi $[n]=a s$ 
namma le $[k u]$ watka niniksi 'And now, if any troops? come back, do not mobilize them at all again' (Hoffner 2009: 238).

In HKM 72 9-13 ninink- is used in a non-military context: $n=$ asta ${ }^{\text {GIS }}$ murta tuel=ma karassand $u<s^{?}>$ karsten $\check{S} A \mathrm{KUR}^{T I M} \mathrm{x}[]$ ninikten $n u=$ war $=$ at pedand $u$ 'Cut down (pl.) murta-trees, but (only) your own cut pieces, and muster the ...-people of the land. And let them transport them (i.e., the timbers)!' (Hoffner 2009: 231). A similar meaning could be found in KUB 21.38 23-4: ${ }^{\mathrm{m}}$ Pihasdus=ma kuedani mēhuni āras nu karū S[ÈD-anza ] NAM.RA ${ }^{\mathrm{MESS}}$ pedi \{erasure\} $\bar{U} L$ namma nininkun 'At the moment that Pihašdu did arrive, it was already winter, and I did not transfer the civilian captives again', for the translation see Hoffner 2009: 284.

In my opinion, in these passages ninink- is better to be interpreted in a more general sense, something like 'to gather', 'to get ready' rather than more specific 'to mobilize'.

Middle forms of ninink- in historical accounts and treaties are also often interpreted as 'to mobilize', e.g. KBo 5.8 I 32-33 ${ }^{\mathrm{LU}} \mathrm{KU} R$ ${ }^{\mathrm{URU}} \mathrm{Kabbubba}=[\mathrm{ma}] \mathrm{KUR} . \mathrm{KUR}^{\mathrm{MES}}{ }^{\mathrm{URU}}$ Gasga $=y a$ hümanda niniktat '(While I was going through the land of Ištalubba), the Kabbubban enemy and all the Kaška lands mobilized (and came against me up on the mountain at Kabbubba)' (CHD L-N: 440), KBo 10.12 II 29$30 \quad\left[\begin{array}{llll}n u & m \bar{a}\end{array}\right] n$ Aziras [sakuw]assarit ZI-nit [IŠTU ERÍN $\left.^{\mathrm{M}}\right]^{\mathrm{EŠ}}$ ANŠE.KUR.RA ${ }^{\text {MEŚ }}$ UL neniktari '[I]f (you) Aziru do not get going [with (your) troop]s and horses with [loy]al intent (and do not attack that enemy), ${ }^{1}$ (CHD L-N: 439) or KUB 21.1 III $46 n u m \bar{a}{ }^{\text {LÚ KÚR }}$ kuiski niniktari 'If some enemy mobilizes (and goes to strike those border territories)' (CHD L-N: 440, sim. HED N: 112). In my opinion, a less specific interpretation, for instance, 'to gather', 'to line up' or, perhaps, 'to get ready' is more appropriate in these passages as well.

However, there are contexts where ninink- likely implies some kind of physical contact or engagement. One of the clearest example is $n=u$ s nininker (KUB 14.1 obv. 72) '(They came and seized the road (before) our troops,) and they attacked/engaged them. (They killed Kišnapili and Partahulla)', cf. HED N: 114 and CHD L-N: $442^{2}$ for the translation. In my opninion, the meaning of ninink- is

\footnotetext{
${ }^{1}$ An Akkadian parallel to this phrase is šumma ${ }^{\mathrm{m}}$ Tette ištu ERÍN ${ }^{\mathrm{MES}}{ }_{-} \check{\text { š }}$ u GISS GIGIR $^{\mathrm{MES}}-\check{s} u$ u ina Š S̀-šu ul inamuš 'If Tette wholeheartedly does not get moving with his troops and chariotry' KBo 1.4 II 17-18, cf. CHD L-N: 439.

${ }^{2}$ The translation 'threw in confusion' in CHD is dubious, since there are no other unambiguous examples for this meaning.
} 
similar in KUB 14.1 obv. $44-45\left[{ }^{\mathrm{m}}\right.$ Maddu]wattas $=a$ [KUR-e] hüman [IS] $]$ BAT namm $[a=a]$ t IŠTU ERÍN ${ }^{\mathrm{MES}}$ pa[nga]rit ninik[ta nu $A N A{ }^{\mathrm{m}} \mathrm{Ku}$ ]panta- ${ }^{\mathrm{D}}$ LAMMA [zahhiya pa] it 'Madduwatta seized the whole [land]. Then he harassed it with the main body of his army and went [to fight] Kupanta-Kurunta'. The meaning 'to mobilize' is hardly appropriate here, since in that case one would expect the army to be in Accusative. Some further likely examples for the meaning 'to engage' or 'to harass' are KUB 50.79 obv? $6 \mathrm{nu}$ $\mathrm{ZAG}^{T U M}$ ninikzi NU.ŠE- $d u$ '([If] he harasses/attacks the border, let (the oracle) be unfavorable'; KBo 2.6 II 55-56 nu DUMU ${ }^{\mathrm{MES}}$ $S U=m a$ EME ēssanzi nu GIDIM nininkiskanzi 'Or are his children slandering? Are they disturbing the dead? (If so, let the lots be unfavorable)' (CHD L-N: 442. sim. HED N: 115) and KUB 50.6 III 43-44 [...] apez INIM-za HUL-lu UL nininkueni 'by that matter will we not disturb? trouble for ourselves?' (cf. HED N: 112, who translate nininkweni as 'stir up').

Similarly, middle forms of ninink- may indicate harassing behavior, cf. the examples in CHD L-N: 441: KUB 31.86 IV 1-3 [(DINGIR $\left.\left.^{\mathrm{MES}}-y\right)\right]$ a kuwapi èssanzi nu ANA PANI DINGIR ${ }^{\mathrm{MES}} \bar{e}$ kuiski niniktari ${ }^{4}$ INA É.EZEN=ya lē kuiski niniktari 'When they are worshipping the gods, let no one become disorderly before the gods, and let no one become disorderly in the festival house (but let the reverence be observed toward all classes of priests)'; KUB 13.4 III 36-8 Š̀̀ É DINGIR ${ }^{\text {LIM }}$ nasma tamēdani ${ }^{\mathrm{E}}$ karimme kuiski nikzi $n=a s=k a n$ mān Š̀̀ É DINGIR ${ }^{L I M}$ niniktari nu hallūwāin iyazi $n=$ asta $\mathrm{EZEN}_{4}$ zahzi. '(If) in a temple or other sacred building some... -person gets drunk(?), if he becomes disorderly inside the temple, so that he causes a quarrel, and disrupts a festival'.

In some contexts ninink- seems to mean 'to move' or 'to remove', cf. e.g. KUB 30.56 III 15 mān=kan DINGIR ${ }^{\mathrm{MES}}$ pédaz nininkanzi 'When they move the gods from (their) place', or KBo 5.3 IV 35-41 dankuwayaz $=m a=s<$ mas $>=k[$ an takn $] a z$ ser arha nininkandu '(If you, Mariya and the men of Hayasa do not keep these oaths, may these oaths (destroy) you with your wives, children

\footnotetext{
${ }^{3}$ The restorations are according to Götze 1968: 10ff. Note though that neither the restoration of the active voice ending nor the restoration of the enclitic =at after namma is certain. The middle form of ninink- would make a smoother interpretation of this passage: «Madduwatta seized the whole [land]. Then he gathered/lined up with the main body of his army and went [to fight] Kupanta-Kurunta».

${ }^{4}$ In duplicates: ninikzi in KUB 13.2 III 17, ni-ni-i[n- ] in KUB 40.56 II 25.
} 
$\ldots$ and) may they remove you from the dark earth', A meaning 'to remove' fits also the contexts when a seal is the object, e.g. KBo $39.831 k \bar{l}=y[a=w] a^{\mathrm{NA} 4} \mathrm{KISSIB}$ apiyakku niniktaru 'When the ancient kings return and examine the lands and the customs, only then shall this seal be removed" .

When peda- is in Dative-Locative, the interpretation of pedi ninink- as 'to remove' is more complicated, since Dative-Locative does not usually designates separation or origin of movement. Note however that according to CHD L-N 441 pedi ninink- is parallel to $s a r \bar{a} d a$ - 'to take up' or just 'to take' ${ }^{7}$, though they are not necessarily synonymous. One could speculate that the use of DativeLocative in pedi ninink- is perhaps similar to Dative of disadvantage ${ }^{8}$. However, since the Dative of disadvantage refers to living beings (Hoffner, Melchert 2008: 258f.), it is better to interpret ninink- as simply 'to move' in such phrases, e.g. KUB 1.1 II 52-3

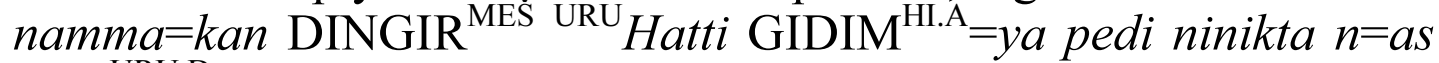

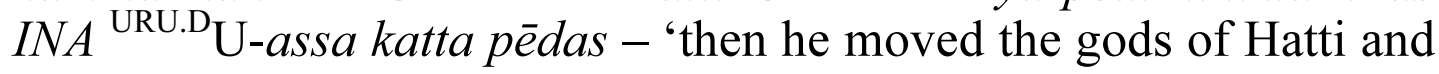
the deceased to (one) place and brought to Tarhuntassa'; KUB 24.13 I 19-20 nu ${ }^{\mathrm{DUG}} K U K \overline{U B}$ A suppi pedi nini $[\mathrm{kz}] i \mathrm{n}=a[t$ šarā(?)] karpzi 'He moves a $k$.-vessel of water to (its) consecrated place and lifts it

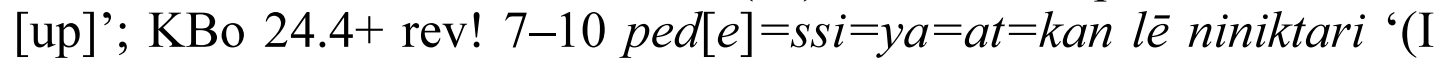
have fixed in place (tarmānun) the king's oath, curse, blood (and) tears. Let it not come up). Let it not be moved' in its place'.

Some kind of displacement is also likely for nininkan in KBo 16.97 rev. 5, $16{ }^{\mathrm{UZU}} \mathrm{ZE}$ ZAG-az nininkan 'The gallbladder was pulled? $^{\text {? }}$ on the right'. Schuol (1994: 296f.) points out that ninink- is used in oracle inquiries similarly to Akkadian $n \bar{a} s a h u$ 'to remove, to pull out', and nasāhu is often used in contrast to kânu 'to remain stationery'. Based on these parallels, nininkan in KBo 16.97 must mean something like 'displaced' or 'pulled'.

${ }_{6}^{5}$ CHD L-N: 442 translates ninink- here as 'to stir up'.

6 'Broken' in Miller 2004: 105f., 'loosened/detached' in CHD L-N: 442, 'be accessed' in HED N: 114. One of the duplicates, KBo 2.3 iv 13, has kinuttaru 'be opened' instead of niniktaru. A similar variation is attested in the Hantitassu ritual, with ninikzi in KBo 11.14 IV 19 and kinuzi in KUB 43.57 IV 17 (see Ünal 1996: 25). Such an alternation does not indicate, however, that ninink- means 'to open', only that both kinu- and nininkcould be used in such contexts. Besides, there are other discrepancies between the texts, for instance, LUGAL-us in KUB 43.57 IV 13 vs. EN.SISKUR in KBo 11.14 IV 15.

${ }_{8}^{7}$ See Shatskov forthcoming.

${ }^{8}$ See Brosch 2014: 67 for examples where Dative-Locative denotes separation. 
Puhvel (HED N: 112) translates ninink- in e.g. KBo VIII 47 obv. 10 karittiyas nininkanta as 'floods will soak in'. However, this interpretation seems to be based on presumed connection of nininkwith nink- 'to satisfy one's thirst', 'to get drunk'. In Akkadian omens verbs like alāku 'to come' or teh $\hat{u}$ 'to come near, approach' are used in similar contexts.

Most difficult to interpret are contexts when ninink- denotes some physical action, when its objects are people, golden objects etc. The passage KBo 26.64 II 9-11 GIS [BA]LAG.DI=ma galgal[turi] GUL-ahta KÜ.GI ${ }^{\mathrm{HI} . \mathrm{A}}=m a \quad n[i]$ nikta $n u=z a=k a n$ [išh] amain dās is translated as '(Ishtar) struck the BALAG.DI- and galgalturi-instruments, she shook ${ }^{\text {? }}$ the 'gold things' and took up a song' in CHD L-N: 441. Alternatively, Hoffner (1998: 60f.) and Rieken (the electronic editon of this text at HPM) interpret this form as 'set in motion', and according to Puhvel (HED N: 113) ninikta here means 'stirred'. Another unclear passage is KUB 58.48 IV 7-8: GAL LU'MEŠ URU Tissaruliya LUGAL-i menahhanda SAG.DU-SU ninikzi. CHD L-N: 441 gives the following translation: '(After the king asks an official why he has come to do battle, when everything is fine,) the chief of the men of Tiššaruliya shakes(?)/nods(?) his head facing the king'. HED N: 111 also translates ninink- as 'shakes'.

In the examples already discussed above ninink- usually corresponds to Akkadian verbs denoting motion or displacement: alāku 'to go, to come', namāsu 'to set out, move; to defect' and $n \bar{a} s a h u$ 'to remove, to pull out'. A further Akkadian comparison for ninink- is sākanu 'to place, put; establish', also 'to inflict defeat', in the expression šākinat $n[u ?-k]$ urati / šākinat tuqunti '(She who) instigates hostilities' parallel to Hittite kurur=ma nininkiskizzi '(She) instigates hostility' (KUB 31.141 obv. 6), see Reiner, Güterbock 1967: 258 and CHD L-N: 439.

Summing up, in some contexts the meaning of ninink- is quite clear - 'to gather/ get ready troops', 'to get ready' (mid.), 'to remove', 'to attack/harass' or 'to behave harassingly'. However, in other contexts it can only be guessed at. Unfortunately, many of these contexts are severely damaged.

Oettinger (2009) argued that all the contextual meanings of ninink- can go back to 'to lift', 'to raise'. While he is correct that the basic meaning of this verb must denote some kind of motion, the meaning 'to lift' in my opinion is not appropriate in many contexts. Besides, there is no unambiguous context with ninink- denoting physical lifting. Moreover, Akkadian verbs in parallel contexts mean 
'to go', 'to come', 'to remove'. The basic meaning 'to move', 'to approach', similar to what is given in the CHD and HED, seems to be the most fitting, even though some contexts are still not entirely clear.

The etymology of ninink- is well established: it goes back to *neik- or, less likely, *niek- (cf. Oettinger 1979: 143). On the assumption that ninink- means 'to rise', Benveniste (1954 : 40) suggested the following cognates for this verb: Lith. su-nikti 'to become involved, assault', OCS vbz-niknoti 'to rise, appear' with aor. nikb (see Hock 2015: 704f. for more Baltic cognates). LIV: 451 also assigns the meaning 'to rise' to this root and adds Greek veĩкo 'quarrel, strife, feud' as a nominal derivative.

The Etymological Dictionary of the Slavic Languages (ESSJa 25: 110, 114-5) connects OCS (vbz)-niknoti, Lith. su-nikti etc. to OCS po-niknoti 'to droop', Old Polish niknać 'disappear', Lith. $n y k t i$ 'disappear' and further to Old Russian nicb 'down', Latv. nīca 'down the river', Skt. nīcá 'below'. It is argued that the semantic difference between these words is due to the preverbs (cf. Bulg. nikna that means both 'to grow' and 'to bow', as well as Czech niknouti 'disappear' and 'to sprout'). The dictionary gives the following basic meanings for this root: 'to fall on, run against', 'to rise, grow' and 'to come down, disappear'. Formally, however, the connection with Skt. $n \bar{l} c \bar{a}\left(<* n i-h_{3} k-\right.$ - cf. Skt. $n i$ 'downwards') is impossible, since the Lith. nikti and its derivatives did not have laryngeal in the root and are therefore not related, see Derksen 2008: 352f.

Since ninink- does mean 'to move, approach; harass' rather than to 'to lift', it can be compared directly to Lith. ap-nikti 'to assault, beset', $i$-nikti 'to get down to, engage, attack', Lith. su-nikti 'to become involved, assault', and also to synchronically homonymous ap-nikti and $i$-nikti 'to pester, bother'. The specific spatial meanings of OCS vbz-niknoti 'to rise, appear', po-niknoti 'to droop' could be explained by the semantics of the prefixes. All in all, the root *neikseems to denote some kind of energetic approaching (cf. Beekes 2010: 1002).

Maria Kazanskaya has pointed out to me the semantic similarities between Lithuanian descendants of the root $*^{n e i k-}$ and Lat.

\footnotetext{
${ }^{9}$ See the entries in the electronic version of the Lietuviu kalbos žodynas (http://lkzd.lki.lt).
} 
nìtor 'to lean (on), to be supported, to rely on, to struggle, move with effort, to direct one's effort towards a specified goal' (see OLD: 1181). Indeed, some of the meanings are very close, cf. Latin Nos cum maxime consilio studio labore gratia de causa regia niteremur 'While I was striving my utmost in the king's matter, by dint of thought, zeal, hard work, and personal influence' (Cic. Fam. I 5a, 2) and Lith. Ninkù $i$ darba pasilikęs 'remaining behind (after work), I put my utmost into my work' or postisque sub ipsos nituntur gradibus 'before the very doors they press forward step by step' (Verg. A. 2, 441-2) and Dar blogiau, kai velniai žmogy apnyksta 'It is even worse when a man is beset by demons (devils)' or Tuoiaus kayp fíunis apnikta 'He immediately attacked like a dog' (Hock 2015: 704).

The meaning 'to rely on' is not attested for Lithuaninan verbs, but it may be similar to OCS (po-)niknoti 'to droop, wilt', Russ. приникнуть 'to press oneself close to, cling to'.

Formally, nītor (ppp. nīxus/nīsus) may well go back to PIE *neik-, even though the provenience of -t- is not certain, cf. de Vaan 2008: 410f. However, it is often connected to Lat. conniveo 'to be tightly closed' and further to PIE * $k_{n e i g}{ }^{w h}$-, since the variants gnitus and gnixus are attested in Paul's epitome of Festus' De verborum significatu $^{10}$. The loss of a velar before a nasal in initial clusters occurred in the $2^{\text {nd }}$ century BCE (see Meiser 1998: 112f., Kazansky 2017: 25), before the composition of Festus' and Varrius' lexica; nevertheless, the forms gnitor and gnixus could be archaisms, since the lexicon is known to have preserved some very early forms. Note, however, that the velar is missing in prefixed verbs, e.g. connitor (cōnisus Pl. Mil. 29), énītor (Pl. Ps. 1279) or renītor. In view of a strong semantic similarity between nītor and Baltic and Slavic verbs, it is more likely that gnitor and gnixus are secondary, perhaps formed in analogy to nōscō/gnōscō or other words with etymological *\#Kn-.

Summing up, the underlying meaning of Hittite ninink- is 'to move, approach', even though some contexts with ninink- remain unclear. Hitt. ninink- has cognates in Baltic (Lith. ap-ninkì, -nikti 'to assault, beset', $i$-nikti 'to get down to, engage, attack'), Slavic (OCS po-niknoti 'to droop') and Greek (veĩ火os 'quarrel, strife, feud'), all going back to PIE *neik- with the tentative meaning 'to approach energetically'. Due to the semantic similarities between the Balto-Slavic verbs and Lat. nitor 'to lean (on), to struggle, to

${ }^{10}$ Gnitus et gnixus a genibus prisci dixerunt (Paul. Fest. p. 96. M). 
move with effort', it is very likely that the Latin verb also belongs to this root.

\section{References}

Beekes, R. S. P. 2010: Etymological Dictionary of Greek. Leiden: Brill.

Benveniste, E. 1954: Études Hittites et Indo-Européenes. Bulletin de la Société de linguistique de Paris 50, 29-43.

Brosch, C. 2014: Untersuchungen zur hethitischen Raumgrammatik. Berlin; Boston: De Gruyter.

CHD - Guterbock, H. G., Hoffner, H., van den Hout, Th. 1989-: The Hittite Dictionary of the Oriental Institute of the University of Chicago. Chicago.

de Vaan, M. 2008: Etymological Dictionary of Latin and the other Italic Languages. Leiden: Brill.

Derksen, R. 2008: Etymological Dictionary of the Slavic Inherited Lexicon. Leiden: Brill.

ESSJa - Etymological Dictionary of Slavic Languages. Proto-Slavic Lexical Stock. 1974-. Ed.: O. Trubachev. Moscow.

Этимологический словарь славянских языков. Праславянский лексический фонд. 1974-. Под ред. О.Н. Трубачева. М.: «Наука»,

Götze, A. 1968: Madduwattaš. 2., unveränderte Auflage. Darmstadt: Wissenschaftliche Buchgesellschaft.

HED - Puhvel, J. 1984-: Hittite Etymological Dictionary. Berlin; NewYork; Amsterdam: Mouton De Gruyter.

HEG - Tischler, J. 1977-: Hethitisches Etymologysches Glossar. Innsbruck.

Hock, W. et al. 2015: Altlitauisches etymologisches Wörterbuch. Hamburg: Baar.

Hoffner, H. 2009: Letters from the Hittite Kingdom. Atlanta.

Hoffner H., H. Craig Melchert. 2008: A Grammar of the Hittite Language. Winona Lake: Eisenbrauns.

Kazansky, N. 2017: An Outline of Latin Phonology. Moscow. Казанский, Н. Н. 2017: Очерк фонологии латинского языка. Москва.

LIV - Lexikon der indogermanischen Verben, 2001. $2^{\text {nd }}$ ed. Ed.: H. Rix. Wiesbaden: Reichert.

Meiser, G. 1998: Historische Laut- und Formenlehre der lateinischen Sprache. Darmstadt: Wissenschaftliche Buchgesellschaft.

Miller, J. 2004: Studies in the Origins, Development and Interpretation of the Kizzuwatna Rituals. Studien zu den Boğazköy-Texten 46. Wiesbaden: Harrassowitz.

Oettinger, N. 1979: Die Stammbildung des hethitischen Verbums. Nürnberg.

Oettinger, N. 2009: Semantik und Pragmatik indogermanischer Verben: hethitisch ninink- * 'heben' und anderes. In: E. Rieken, P. Widmer (eds.) Pragmatische Kategorien. Form, Funktion und Diachronie. Wiesbaden, 197-203. 
OLD - Oxford Latin Dictionary. 1968. Ed:. P. G. W. Glare et al. Oxford University Press.

Reiner, E., Güterbock, H. G. 1967: The Great Prayer to Ishtar in Its Two Versions from Boğazköy. Journal of Cuneiform Studies 21, 255266.

Schuol, M. 1994: Die Terminologie des hethitischen SU-Orakels. Eine Untersuchung auf der Grundlage des mittelhethitischen Textes KBo XVI 97 unter vergleichender Berücksichtigung akkadischer Orakeltexte und Lebermodelle, II. Altorientalische Forschungen 21, $247-$ 304.

Shatskov, A. forthcoming: Non-spatial Use of Preverbs in Hittite.

Ünal, A. 1996: Studies in ancient Anatolian magical practices. The Hittite ritual of Hantitaššu from the city of Hurma against troublesome years. Ankara. 